\title{
US fast-breeder reactor fights for survival after Clinton trims budget
}

Washington. This week the US Congress will lift the curtain on what could prove to be a long, hot summer of conflict over whether to close the country's last major experimental nuclear reactor.

Energy secretary Hazel O'Leary is likely to be questioned about the Integral Fast Reactor (IFR) at the Argonne (Illinois) National Laboratory when she testifies today (Thursday, 22 April) before a House of Representatives appropriations subcommittee. The Clinton administration originally sought to terminate the project, being carried out at Argonne's Idaho site. But after strong lobbying from local congressmen, the president agreed to request $\$ 20$ million - down from a current budget of $\$ 125$ million - for continued research into the recycling of the class of heavymetal elements known as actinides (plutonium and other fissile elements).

This compromise, however, appears to have satisfied no one. In the months ahead, supporters will request sufficient funds to keep the reactor running and prepare it for commercial application, while opponents will demand closure.

The winding down of the reactor is the main component in the Department of Energy's plan to reduce spending on its nuclear programme from \$345 million to \$284 million in the 1994 fiscal year, which begins on 1 October. But laboratory officials say that the high cost of terminating the project means that little money will be saved.

The chairman of the House appropriations subcommittee, Tom Bevill (Democrat, Alabama) supports the reactor and is likely to put additional money into his funding bill. His counterpart in the Senate, J. Bennett Johnston (Democrat, Louisiana), has also supported the project. When the legislation moves to the floor of each house, the vote will test the strength of the pro- and anti-nuclear energy lobbies for the first time since Congress voted ten years ago to shut down the Clinch River fast breeder reactor project in Tennessee.

The IFR programme employs 1,000 people at Idaho and another 500 at Argonne's main site in Illinois. Supporters say that the reactor design is "intrinsically safe", with no possibility of a meltdown because expansion of the fuel upon overheating will moderate the reaction and lower the temperature. They say the design could not only generate cheap power safely, but would also recycle existing nuclear waste from generators and weapons, producing small volumes of waste with a relatively short half-life of 200 years.

"This is potentially the biggest energy source bar none", says Argonne's director of engineering, Chuck Till, who has led the project since its inception in 1984 . He points out that the amount being spent on IFR around $\$ 120$ million a year - is "down by

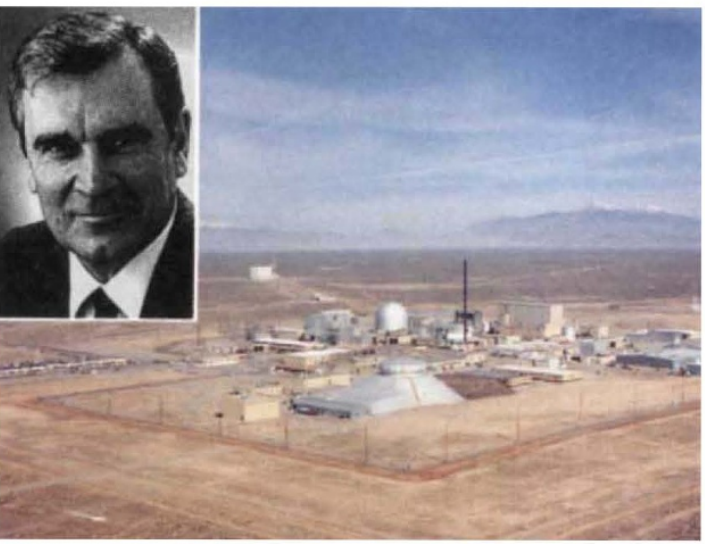

The Integral Fast Reactor in the Idaho desert and project director Chuck Till.

a factor of ten" from the budget for fastreactor research a decade ago.

Representative Richard Durbin (Democrat, Illinois), a supporter of the IFR programme, says it will be "an uphill battle" to save the reactor. "Those unalterably opposed to nuclear power will never favour it, but if you believe that nuclear power can be used responsibly, you will support it", he says.

As with other 'big-science' programmes, the potential for collaboration with the Japanese is being cited by both opponents and proponents of the IFR. The Department of Energy would like to attract a foreign sponsor - almost certainly Japan - to help support its proposed actinide recycling pro- gramme. But cuts in federal support are likely to repel, rather than attract, overseas investment.

The environmental lobby does not accept the claims being made on behalf of IFR and is concerned that the administration may back away from campaign promises to abandon research on nuclear power. Scott Denman, director of the Safe Energy Communication Council, fears that the administration's early concessions on actinide recycling mean it has lost the will to kill the reactor. "When a programme moves in this way it sends a message that it will continue", he says. "They've spent $\$ 700$ million on this since 1984 , and I'm worried that they'll find ways of keeping it going."

The debate on the reactor involves not just its safety or its impact on the environment but also its implications for nuclear proliferation. Supporters of the reactor say that its output of plutonium, neptunium and americium is of no military value and that it can thus be sold to countries, ranging from Japan to Ukraine, that need plants to consume existing nuclear wastes. Their opponents say that any country buying a fast reactor could adapt it to create fissile material for military purposes.

The last time the project was challenged in Congress - last summer in a vote called by since-retired Michigan congressman Howard Wolpe - it was endorsed by a 2:1 margin. This year brings a new administration and more than a hundred new members unfamiliar with the IFR but united in their professed hostility to the financing of (other people's) pet projects. For the Integral Fast Reactor at Argonne, that hostility could prove fatal.

Colin Macilwain

\section{France to close four observatories}

Paris. France has decided to close its four national observatories to meet the growing costs of its contributions to international facilities. The Pic-du-Midi observatory will be closed in 1998, with the others - Nançy, Haute-Provence and Côte d'Azur - staying open at least until the end of the decade with a smaller staff and budget as a postponement but not a reprieve.

Closure of Pic-du-Midi will save FF13.6 million (US\$2.5 million) a year, with reductions in the others amounting to another FF50 million. The growing importance of international facilities justifies the loss of the smaller national observatories, accord- ing to the Institut National des Sciences de l'Univers (INSU), which controls spending on large astronomical observatories. France is paying FF300 million towards construction of the Very Large Telescope in Chile as a member of the European Southern Observatory and FF87 million to build a solar telescope THEMIS with the Italians in Tenerife, Canary Islands. It also spends FF17 million a year to operate a telescope on Mauna Kea and FF31.4 million for a submillimetre radioastronomy telescope built with Germany and Spain. The institute's annual budget has remained static at around FF1,200 million. Declan Butler 